Original article

\title{
Histochemistry and histology in planktonic ecophysiological processes determination in a temperate estuary (Mondego River estuary, Portugal)
}

\author{
M.R. Pastorinho ${ }^{\text {a, }}$, C.P. Antunes ${ }^{\text {a }}$, J.C. Marques ${ }^{\text {b }}$, M.L. Pereira ${ }^{\text {a }}$, \\ U.M.M. Azeiteiro ${ }^{\text {b }}$, F.M. Morgado ${ }^{\text {a }}$ \\ a Departamento de Biologia, Campus de Santiago, Universidade de Aveiro, 3810-193 Aveiro, Portugal \\ ${ }^{b}$ IMAR - Departamento de Zoologia, Universidade de Coimbra, Portugal
}

\begin{abstract}
Zooplankton communities in temperate climates exhibit well documented seasonal variability. The reasons proposed to explain this kind of behaviour range from the effect of physical-chemical conditions (salinity, nutrients, temperature) growth rates, mortality, migration rates, food availability and predation. It is noticeable that the majority of the factors mentioned are external to the organisms, being environmental factors responsible for time dependent changes in zooplankton abundance. A question may arise from this conclusion, namely, "Could zooplankton blooms, in temperate climates, be mainly modelled by the internal physiological predispositions of the individual organisms?" Or, in a more "functional" formulation, "Could gonads be the baseline regulators of zooplankton abundance?". This study answers this pertinent question, assuming as a basic assumption that the reproductive potential of these organisms is constant, being controlled by extrinsic factors. For this purpose, histological and histochemical techniques were applied to the mysid Mesopodopsis slabberi, a key species in the Mondego River estuary, in order to establish a scale of gonadic development that would allow comparisons between high and low density periods. Histology reveals itself as the ideal base to establish a tool for the evaluation of the gonadic masses by allowing to calculate oocyte dimensions (trough biometry) and determine its maturity status through calculation of the N/C ratio and histochemical analysis (PAS and Tetrazonium reaction for proteins). Upon creation, validation and application of the formerly described tool, the most prominent result emerging from this study is the confirmation of the initial assumption: seasonal variability in zooplankton densities reflects advantageous or disadvantageous external factors acting over a latent reproductive potential. Moreover, this work confirms histology and histochemistry as valuable approaches to the determination of planktonic ecophysiological processes.
\end{abstract}

(C) 2003 Éditions scientifiques et médicales Elsevier SAS. All rights reserved.

Keywords: Histochemistry; Histology; Zooplankton; Reproduction; Ecological forcing; Reproductive potential; Temperate estuary; Mesopodopsis slabberi

\section{Introduction}

Seasonal fluctuations in zooplankton densities in temperate climates have been known for a long time and the numerous studies conducted have identified a vast number of factors responsible for these phenomena. The explanations provided have varied in accordance with the prevalent combination of environmental/biological parameters present at each studysite.

Available papers, concerning the interpretation of seasonal cycles, usually present a set of conclusions contemplating a complex conjunction of these factors (Castel and Courties, 1982; Davis, 1984; Deevey, 1971; Fulton, 1984; Gaughan and Potter, 1995; Herman et al., 1968; Mackas,

\footnotetext{
* Corresponding author.

E-mail address: mpastorinho@bio.ua.pt (M.R. Pastorinho).
}

1992; Ryan et al., 1986), although only a limited number of them are identified as being primely responsible, being modelled, in a somewhat limited way, by the remaining others. In this situation, there are environmental parameters, such as temperature and salinity (Greenwood, 1981; Kouwenberg, 1994; Ladurantaye and Lacroix, 1980; Mallin, 1991; Tundisi, 1970; Wooldridge, 1986), nutrients (Gaughan and Potter, 1995; Herman et al., 1968) and hydrology (Castel and Courties, 1982; Mackas, 1992; Ryan et al., 1986). Regarding biological factors, citations range from food availability(Deevey, 1971; Fulton, 1984; Herman et al., 1968; Ladurantaye and Lacroix, 1980; Mallin, 1991), predation and competition (Castel and Courties, 1982; Davis, 1984; Greenwood, 1981; Mackas, 1992; Morgado, 1993), growth rates (Fulton, 1984), mortality (Johnston and Nothcote, 1989) and behaviour sensu lato (Davis, 1984). 
Some authors even suggested that variation in zooplankton densities throughout the year may be due to sampling errors (Allen, 1984; Davis, 1984; Gaughan and Potter, 1995; Mallin, 1991; Morgado, 1993; Wooldridge, 1986), differences in sampling gear, procedures and or observers and the time scale of observations (Allen, 1984).

A basic assumption, not open to questioning, is that any population, great or small at high or low latitudes, in winter or summer, depends, in reproductive terms, on the production index of eggs among females of the population. Many authors have produced proof of various interactions of ecological/biological parameters and egg production rates, such as the close correlation between the number of eggs produced/temperature/food availability found by Rodrigues et al. (1995) in the copepod Acartia grani, or number of embryos/female size/temperature/season as shown by Greenwood et al. (1989) for Mesopodopsis slabberi. Based on another mysid shrimp, Rhopalophtalmus terranatalis, Wooldridge (1986) postulated a linear relationship between brood size and body length, which he called "fecundity", temperature being the main controlling factor of seasonal fluctuation. The term "fecundity" has been used with different connotations by different authors, but generally represents the concept of "reproductive potential". One of the approaches to this theme came from Ianora and Buttino (1990). When studying the egg production rates of two copepods (Centropages typicus and Acartia clausi), they indicated that "high and low density phases in population numbers may be the outcome of variations in reproductive potential and survival rates of the eggs and immature stages rather than reproductive potential per se" (Ianora and Buttino, 1990). Various authors have stressed the view that changes in reproductive potential (interpreted as "fecundity") may be strongly related to variations in extrinsic biological factors, such as latitude, food availability and quality and physical environmental conditions (mainly temperature and salinity) (Allen, 1984; Greenwood et al., 1989; Greenwood, 1981; Ianora and Buttino, 1990; Mallin, 1991; Mauchline, 1968; Rodrigues et al., 1995). Briefly, this would mean that organisms would exhibit a permanent and uniform capability of reproduction, conditioned not at an internal level, but by the ecological framing that the populations were submitted to.

This concept, apart from being interesting, seemed worth investigating to the present authors. So, the basic hypothesis of this study is that peaks of abundance are due to the conjunctional influence of "beneficial" environmental and ecological variables over a potential continuous fertility in zooplanktonic populations (a continuous capability to attain development - until maturity —of gonadic cells). Lowest densities would correspond to a detrimental influence of these variables, thus resulting in a minimal expression of the potential fertility.

Following this line of thought, Mesopodopsis slabberi Van Beneden (Arthropoda; Crustacea; Malacostraca; Mysidacea) was selected for this study, since it is a widespread organism, present in a wide range of latitudes (varying, accordingly, its reproductive traits) and zooplankton assemblages (Mauchline, 1980). The species, therefore, plays a key role in zooplankton communities, accounting for total available carbon consumptions of up to $70 \%$ (Webb and Wooldridge, 1987); it is a selective grazer with a pronounced impact on phytoplankton communities (Webb and Wooldridge, 1990) and it is the most abundant among 14 species of mysids at the studysite (Azeiteiro et al., 1999). For these reasons, the species presented itself as a natural choice for the authors. In addition, a crucial factor enforced this choice: despite exhibiting an apparent continuous reproduction cycle, in the Mondego estuary, it almost disappears during the months of January, February and August, it possesses, on the other hand, a peak of abundance in October (Azeiteiro et al., 1999); these patterns are thus perfectly suitable to test the hypothesis presented for this study. For the reasons given above, a sampling strategy was designed so as to collect organisms from the months of August and February representing a state of reproductive impairment ("repressed" fertility-low population densities) and from the month of October, representing a state of full expression of reproductive capacity ("unrepressed" fertility—high population densities). If the gonadic organisation, in terms of development and contents of the oocytes, is to be the same in the three sampling periods, then strong evidence will exist that extrinsic factors are, indeed, the real modellers of zooplankton seasonal fluctuations. If not, intrinsic factors play the fundamental role in this process.

Histology and histochemistry were selected as the most suitable methods to determine reproductive potential, since they allow the assessment of internal morphology, functioning and composition of living organisms (in this case, the evaluation of the size, number and state of development of the gonads) as well as the establishment of comparisons regarding these aspects on a time scale.

\section{Materials and methods}

\subsection{Study site}

The Mondego River estuary, located in the Portuguese west coast $\left(40^{\circ} 08^{\prime} \mathrm{N}, 8^{\circ} 50^{\prime} \mathrm{W}\right)$, has an area of $3.3 \mathrm{~km}^{2}$ and a volume of $0.0075 \mathrm{~km}^{3}$ (Gonçalves, 1991). The hydrological basin of the Mondego, with an area of $6670 \mathrm{~km}^{2}$, provides an average run-off rate of $8.5 \times 10^{9} \mathrm{~m}^{3} \mathrm{~s}^{-1}$.

At about $5.5 \mathrm{~km}$ from the sea, the river branches into two arms (North and South), which then converge again near the mouth. In this area, the tidal range is $0.35-3.3 \mathrm{~m}$ and the average residence time is 2 and $9 \mathrm{~d}$ for the North and South arms, respectively. This fact denotes the sheer contrasting characteristics of the two arms. During high tide, the North arm is $5-10 \mathrm{~m}$ deep, while the South is only $2-4 \mathrm{~m}$ deep, being almost totally silted in the upstream areas (Azeiteiro et al., 1999). As a consequence, the circulation in the latter depends largely on the tides and, to a lesser extent, on the 
freshwater discharge from a tributary-the Pranto River, which is controlled by a sluice located $3 \mathrm{~km}$ from the confluence with the Mondego. The organisms used in this study were captured in the vicinity of this sluice. The selected sampling station was characterised by very shallow waters and fine sediments, with large fractions ranging from fine sand to clay and one of the highest organic matter and carbonate contents recorded within the estuary (Marques et al., 1993).

\subsection{Sampling program}

Amongst the various possibilities (as, for instance, the mid-South arm, a commonly used location for past and present studies in the estuary), the Pranto River was chosen for the establishment of the sampling station, because the extensive work of Azeiteiro et al. (1999), had previously demonstrated that the largest mysid populations were recorded in the upstream regions of the estuary, especially at the station located at the Pranto River sluice.

The organisms were captured with a conic net $(40 \mathrm{~cm}$ diameter, $335 \mu \mathrm{m}$ mesh) in sub-surface tows for $3 \mathrm{~min}$ and with a suprabenthic net mounted on a sledge (40 cm diameter, $500 \mu \mathrm{m} \mathrm{mesh}$ ) in suprabenthic tows for $5 \mathrm{~min}$. The animals were then immediately transported to the laboratory in 1001 containers.

\subsection{Laboratory procedures}

Ovigerous mature females (identifiable by their brood pouch-empty, with eggs, with eyeless or eyed embryos) (Mauchline, 1980) were selected under a dissecting microscope and fixed in Bouin's solution (due to the minute dimension of the organisms, selective fixation of the gonads is virtually impossible).

\subsection{Histological techniques}

The histological processing of the specimens was performed using standard procedures, slightly modified due to the peculiar nature of the biological material.

These consisted of: fixation (in Bouin's solution), paraffin embedding, sectioning ( $7 \mu \mathrm{m}$ thickness), mounting and hematoxylin-eosin staining (Drury and Wallington, 1980). The slides obtained were observed through light microscopy in order to record the arrangement of the ovaries and determine the maturity stage of the various germ cells.

\subsection{Biometry}

The carapace (tip of the rostrum to the medial cleft) of seven fresh females in each of the 3 months of the study, was measured using an ocular micrometer with $0.05 \mathrm{~mm}$ accuracy. The relationship between carapace length (CL) and total length (TL) has been determined by Nekrashova and
Rakitina, 1968 (Mauchline, 1980), who established the following equation:

$$
\mathrm{TL}=2.5 \times \mathrm{CL}+0.012 \mathrm{~min}
$$

Measurements of oocytes were carried out using an ocular micrometer at $0.05 \mathrm{~mm}$ accuracy. The calculation of the N/C (nucleus/cytoplasm) ratio, the ratio between the area of the nucleus and the area of the cytoplasm (Cuzin-Roudy and Amsler, 1991), was always performed. Three maturation stages were considered: immature (lacking yolk cytoplasmic inclusions; $\mathrm{N} / \mathrm{C}$ ratio $=42.12 \%$ ), vitellogenic (partly presenting cytoplasmic accumulation of yolk; N/C ratio $=23.92 \%$ ) and mature (cytoplasm totally occupied by yolk and reduced to a thin layer at the periphery of the cell; N/C ratio $=5.26 \%$ ). The maximum diameters of all oocytes present in the ovary of the seven females were measured each month.

\subsection{Histochemistry}

In order to determine the chemical nature of the different components present in the oocytes (especially cytoplasmatic inclusions), paraffin sections were processed according to standard histochemical protocols. These included: Periodic Acid Schiff method (PAS) (with and without alumhematoxylin as a counterstain) for carbohydrates (Kiernan, 1990) and the Tetrazonium reaction for proteins (Ganter and Jollés, 1969). Lipid identification could not be performed due to the primary fixation with Bouin's solution, which removes the majority of these organic compounds from the tissues.

\subsection{Statistics}

All statistical analyses of data collected during the study were performed using STATISTICA 6.0 Software Package. The size differences among adult ovigerous females, mature stage of oocytes, immature stage of oocytes and vitellogenic stage of oocytes were investigated through a one-way analysis of variance (ANOVA). The size differences among oocytes according to their maturation stage were analysed by means of a two-way ANOVA, in which cell maturity status and month by cell maturity status were the two factors considered in the analysis. All the measurements taken from each sample analysed were considered as replicates. Prior to the analysis, data were subjected to an angular transformation, which homogenised the variances in all the cases.

\section{Results}

\subsection{Biometrics}

\subsubsection{Female size}

Female size in August ranged from 4.64 to $5.64 \mathrm{~mm}$ (average $5.05 \mathrm{~mm}$ ), in October, ranged from 5.09 to $5.76 \mathrm{~mm}$ (average $5.42 \mathrm{~mm}$ ) and in February, ranged from 5.09 to $7.51 \mathrm{~mm}$ (average 6.48) Table 1. 
Table 1

Size of adult ovigerous females of Mesopodopsis slabberi in each sample (values in $\mathrm{mm}$ )

\begin{tabular}{llll}
\hline & August & October & February \\
\hline Minimum & 4.64 & 5.09 & 5.09 \\
Maximum & 5.64 & 5.76 & 7.51 \\
Average & 5.05 & 5.42 & 6.48 \\
$\begin{array}{l}\text { Standard } \\
\text { deviation }\end{array}$ & 0.37 & 0.26 & 0.96 \\
\hline
\end{tabular}

Statistical analysis showed a significant difference in animal size between the three sampling periods $(P<0.001)$ Table 4.

\subsubsection{Cell size}

The size of oocytes during the study period varied from $20 \mu \mathrm{m}$ (stage I, October and February) to $590 \mu \mathrm{m}$ (stage III, February). The average values obtained for each development stage through the study period were: for immature cells, $41.76 \mu \mathrm{m}$ in August, $45.76 \mu \mathrm{m}$ in October and $48.93 \mu \mathrm{m}$ in February, for vitellogenic cells, the average values were $106.92 \mu \mathrm{m}$ in August, $111.30 \mu \mathrm{m}$ in October and $123.33 \mu \mathrm{m}$ in February and for mature cells, the average values were $344.00 \mu \mathrm{m}$ in August, $272.08 \mu \mathrm{m}$ in October and $395.5 \mu \mathrm{m}$ in February Table 2.

A two-way ANOVA showed highly significant $P$ values for the distribution of cell size by maturation state $(P<0.001)$ and within the same month $(P<0.001)$ as well as significant values for the variations between months $(0.05>P>0.01)$ Table 5. Statistical analysis applied on data with respect to cellular diameters for each stage during each month revealed significant results only for the mature stage $(P<0.001)$. The immature and vitellogenic stages exhibited no statistical differences $(P>0.10$ and $P<0.25$, respectively Tables 6-8.

\subsection{Staging of the oocytes}

A total of 70 gonadic masses from M. slabberi females containing oocytes in different developmental stages were analysed.
Table 4

One-way ANOVA of the size of adult ovigerous females of Mesopodopsis slabberi during the period of the study. The null hypothesis is that the size of the organisms does not differ between samples

\begin{tabular}{lllll}
\hline Source of variation & $\mathrm{df}$ & MS & $F \mathrm{~s}$ & $P$ \\
\hline Sampling period & 2 & 0.00 & 29.87 & $P<0.001$ \\
\hline $\begin{array}{l}\mathrm{df}=\text { degrees of freedom; } \\
\text { probability value. }\end{array}$
\end{tabular}

Microscopic observations of histological sections, complemented with descriptions from other crustaceans (Cuzin-Roudyand Amsler, 1991; Kulkarni et al., 1991; Lanteigne et al., 1996; Ritchie et al., 1996; Sandoval Quintero and Garcia, 1998), allowed the establishment of three developmental stages. Unlike the supporting references, the objective of this work was not to create a practical scale to accurately identify each stage (hence the reduced number of stages considered), but rather to obtain basic criteria, reliable, but at the same time allowing plasticity, in which to anchor comparisons among gonads of the different sampling periods.

The three considered stages were:

\subsubsection{Stage I: immature}

The cells are in the oogonial state or are young oocytes. These cells generally lie in the ventral zone of the ovary, are spherical in shape and measure on average $45 \mu \mathrm{m}$ (grand average for the three sampling periods; Table 2. The cytoplasm is extremely narrow and the nucleus is centrally located, with an N/C ratio of $42.12 \%$ Table 3 and basophilic (hematoxylin binding). They exhibit a negative response to the PAS technique, and a weak, positive response to Tetrazonium reaction Figs. 1B,C, 2B,D and 3A,B,D.

\subsubsection{Stage II: vitellogenic}

The cells are maturing oocytes that started and continued the process of accumulating yolk. They range from an early stage, previtellogenesis, characterised by the accumulation of glycoproteins and a later stage, vitellogenesis, characterised by the accumulation of lipidic yolk (Cuzin-Roudy and

Table 2

Minimum, maximum and average size of immature (Im), vitellogenic (Vit) and mature (Mat) oocytes in Mesopodopsis slabberi and respective standard deviations (values in $\mu \mathrm{m}$ )

\begin{tabular}{|c|c|c|c|c|c|c|c|c|c|}
\hline & August & & & October & & & Febru & & \\
\hline & $\operatorname{Im}$ & Vit & Mat & Im & Vit & Mat & Im & Vit & Mat \\
\hline Minimum & 30 & 70 & 260 & 20 & 60 & 200 & 20 & 40 & 290 \\
\hline Average & 41.8 & 106.9 & 344.0 & 45.8 & 111.3 & 272.1 & 48.9 & 123.3 & 395.5 \\
\hline Maximum & 60 & 150 & 410 & 60 & 190 & 330 & 90 & 180 & 590 \\
\hline $\begin{array}{l}\text { Standard } \\
\text { deviation }\end{array}$ & 8.7 & 22.6 & 39.3 & 12.0 & 41.4 & 31.8 & 15.5 & 55.5 & 76.3 \\
\hline
\end{tabular}

Table 3

$\mathrm{N} / \mathrm{C}$ ratio (= nucleus/cytoplasm ratio), in percentage, for the three maturity stages considered in the 3 months of the study

\begin{tabular}{|c|c|c|c|c|c|c|c|c|c|}
\hline & \multicolumn{3}{|c|}{ Immature } & \multicolumn{3}{|c|}{ Vitellogenic } & \multicolumn{3}{|l|}{ Mature } \\
\hline & August & October & February & August & October & February & August & October & February \\
\hline Average & 72.01 & 25.29 & 29.07 & 29.31 & 18.64 & 23.82 & 5.96 & 8.67 & 1.13 \\
\hline Total average & 42.12 & & & 23.92 & & & $5.26^{\mathrm{a}}$ & & \\
\hline
\end{tabular}

Total average $\quad 42.12$

23.92

$5.26^{\mathrm{a}}$

${ }^{a}$ The ANOVA results show significance in cell size variation for mature oocytes, hence the average is presented only as a term of comparison. 
Table 5

Two-way ANOVA of the oocyte size of Mesopodopsis slabberi distributed by maturation state, during the period of the study. The null hypothesis is that the oocyte's size does not differ between samples and maturity status

\begin{tabular}{|c|c|c|c|c|}
\hline Source of variation & df & MS & $F \mathrm{~s}$ & $P$ \\
\hline Month & 2 & 0.01 & 8.21 & $P<0.001$ \\
\hline Cell maturity status & 2 & 0.01 & 838.41 & $P<0.001$ \\
\hline Month by cell maturity status & 4 & 0.01 & 2.70 & $0.05>P>0.01$ \\
\hline
\end{tabular}

Amsler, 1991). Based on investigations on the red swamp crayfish Procambarus clarkii, Kulkarni et al. (1991) postulated that oocytes themselves are capable of synthesising (as well as withdraw from extra-cellular sources) the yolk that they continuously store during the maturation process.

Vitellogenic cells generally lie in the intermediate/dorsal zone of the ovary, are cubic or prismatic and measure on average $110 \mu \mathrm{m}$ (grand average for the three sampling periods; Table 2]. The nucleus is centrally located, the N/C ratio is $23.92 \%$ Table 3 and the cytoplasm is mainly basophilic. They exhibited great variability in response to the PAS technique, mirroring a wide range of situations, from the presence of sparse droplets of glycoprotein to the occupation of high percentages of the cytoplasm (but without noticeable cell swelling).

These cells also showed a strong positive response to the Tetrazonium reaction for proteins, but weaker for glycoprotein droplets Figs. 1A,C,D, 2A,E,F and 3A,B,D-F)

\subsubsection{Stage III: mature}

The cells are fully mature oocytes that have completed the process of yolk synthesis/accumulation (Kulkarni et al.,

\section{Table 6}

One-way ANOVA of the immature stage of oocytes of Mesopodopsis slabberi during the period of the study. The null hypothesis is that all the immature cells do not register any variation between samples

\begin{tabular}{lllll}
\hline Source of variation & $\mathrm{df}$ & MS & $F \mathrm{~s}$ & $P$ \\
\hline Sample & 2 & 0.01 & 2.06 & $P>0.10$ \\
\hline $\begin{array}{l}\mathrm{df}=\text { degrees of freedom; } \\
\text { probability value. }\end{array}$
\end{tabular}

Table 7

One-way ANOVA of the vitellogenic stage of oocytes of Mesopodopsis slabberi during the period of the study. The null hypothesis is that all the vitellogenic cells do not register any variation between samples

\begin{tabular}{lccc}
\hline Source of variation & df & MS & $P$ \\
\hline Sample & 2 & 0.02 & 0.97 \\
\hline df = degrees of freedom; & MS $=$ mean square; $F s=$ test value; $P=$
\end{tabular}
probability value.

Table 8

One-way ANOVA of the mature stage of oocytes of Mesopodopsis slabberi during the period of the study. The null hypothesis is that all the mature cells do not register any variation between samples

\begin{tabular}{lllll}
\hline Source of variation & df & MS & $F$ s & $P$ \\
\hline Sample & 2 & 0.13 & 36.76 & $P<0.001$ \\
\hline
\end{tabular}

$\mathrm{df}=$ degrees of freedom; $\mathrm{MS}=$ mean square $F s=$ test value; $P=$ probability value.
1991) (or are close to completion). They are generally located on the dorsal-lateral wall of the ovary, present a spherical appearance, measuring $337 \mu \mathrm{m}$ (grand average for the three sampling periods; Table 2. The nucleus is usually located at the periphery of the cell and is surrounded by a thin layer of cytoplasm, which is almost totally filled by yolk (except for a thin layer that runs in the inner side of the cellular membrane, very basophilic and with a strong positive reaction to the PAS technique), causing the cell to swell very prominently. Statistics indicated, unlike other maturation stages, a significant difference from month to month, hence the N/C ratio is not obtainable, but solely as a means of comparison, the grand average was calculated to be $5.26 \%$. The yolk inclusion exhibited a moderate positive reaction to the PAS technique, due to the presence of polysaccharide residues. The Tetrazonium reaction for proteins was not applied to any cells at this stage of maturation, but a weak positive reaction in the yolk would be expected along with a stronger one at the periphery where glycoproteins are present Figs. 1B, 2B-2D and 3C)

\section{Discussion}

The main aim of this paper is to evaluate the hypothesis that proposes variability in zooplankton communities as a function of extrinsic forcing, superimposed upon intrinsic reproductive potential. In order to test the hypothesis, a histologically based arbitrary scale was established, as a means of comparison between the different samples collected; numerically obtained and statistically validated.

The evaluation of the chemical composition, using histochemistry, indicated the existence of differences between development stages, and different samples, in terms of the accumulation of reserve substances, nominally glycoproteins, proteins and, indirectly, lipids.

Despite its limited descriptive capacity (it includes only three generic categories), the scale created is easily comparable, identifiable and interchangeable with similar ones established for Decapoda, Amphipoda, Euphausiacea and Copepoda crustaceans (Cuzin-Roudyand Amsler, 1991; Kulkarni et al., 1991; Lanteigne et al., 1996; Ritchie et al., 1996; Sandoval Quintero and Garcia, 1998), broadening the set of conclusions and creating the potential for forthcoming extrapolations not only to the species considered in this study but also to plankton in general.

The use of the scale showed the occurrence of the three stages of gonadal development both in high and low density epochs (October, August and February, respectively, meaning that all three pre-defined development stages occur in each of the three sampling periods). Chemical analyses for each of the stages, inferred through histochemistry, demonstrated a constant composition in the specimens sampled from the three scenarios and that constancy being extended within the same developmental stage. It was observed that developing oocytes were characterised by an initial lack of storage of yolk (Stage I), followed by the accumulation/ 

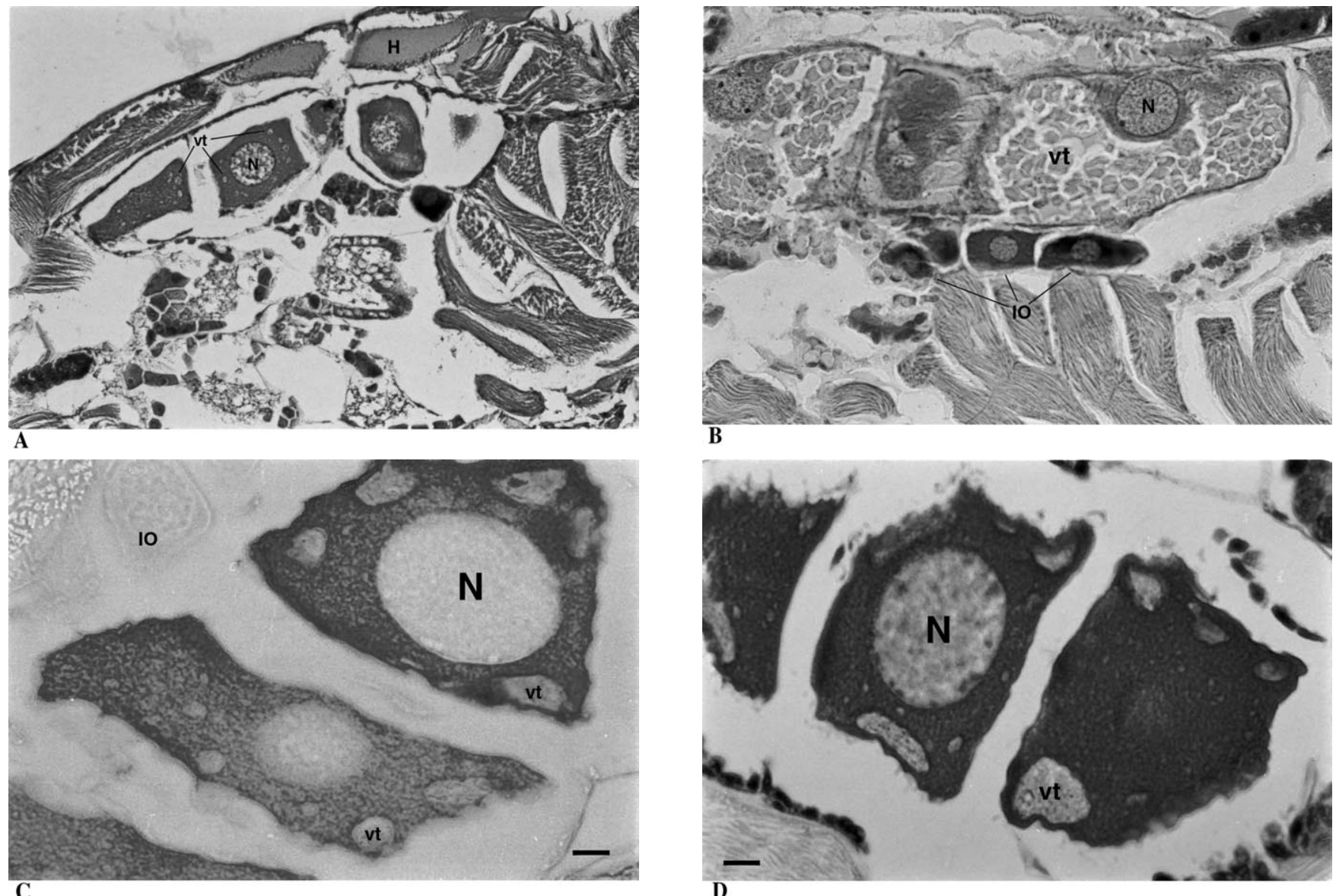

B

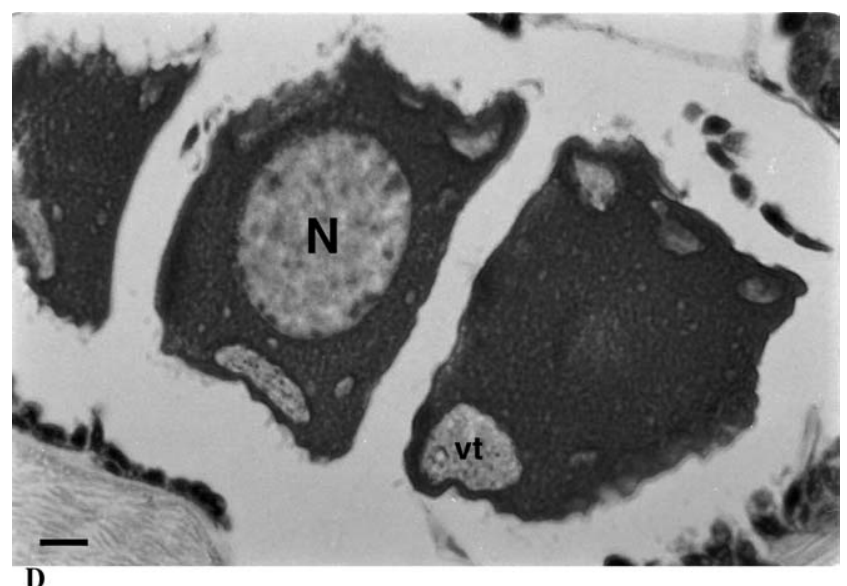

Fig. 1. Mesopodopsis slabberi longitudinal sections. (A) HE (hematoxilin-eosin) staining showing vitellogenic oocytes. Yolk droplets (vt) present in the cytoplasm (total magnification $=235 \times$, scale bar $=50 \mu \mathrm{m}$ ). (B) HE staining showing mature oocytes. The yolk (vt) occupies the majority of the cytoplasm. Note the simultaneous existence of mature and immature oocytes (IO) (total magnification $=235 \times$, scale bar $=50 \mu \mathrm{m}$ ). $(\mathrm{C})$ PAS technique applied to vitellogenic oocytes. Vitellum of glycoproteic nature present in droplets (vt) throughout the cytoplasm. Immature oocyte (IO) denoting the total absence of these compounds (total magnification $=929 \times$, scale bar $=10 \mu \mathrm{m}$ ). (D) PAS technique applied to vitellogenic oocytes, alum-hematoxylin as a counter stain rendering vitellum droplets of glycoproteic nature dispersed throughout the cytoplasm more visible (total magnification $=929 \times, \mathrm{scale}$ bar $=10 \mu \mathrm{m})(\mathrm{H}=\mathrm{heart}$; IO $=$ immature oocyte; $\mathrm{N}=$ nucleus; $\mathrm{vt}=$ vitellum).

production of glycoproteins and lipidic yolk (Stage II) and, in the most advanced stage, only of great quantities of lipidic yolk (as shown by the fact that it is the only stage where notorious gaps in the cytoplasm were observed, due to the removal of the lipids by the used fixative- Bouin's solution-in the histological processing). The latter represents full maturity and, consequently, effective reproductive capacity (Stage III). The overall conclusion from both of these observations is that these organisms exhibit continuous reproductive ability.

It was also shown that the size of Stage III oocytes in months outside the reproductive peak (August and February) is much bigger than that observed during the peak period (October). The idea, proposed by some authors, of environmentally dependent phenotypic plasticity in reproductive patterns, that would allow species to cope with seasonality is, thus, strengthened by this work (Bradoshaw, 1973; Levins, 1968; Mark, 1982). Developmental plasticity in reproductive traits may be an important mechanism of life-history variation leading to $k$-selected (delayed reproduction, larger body sizes, smaller reproductive efforts, producing large young) or $r$-selected (the opposite) populations as a response to environmental changes (Giesel, 1976; Johnston, 1985).

One could question whether the size of the females investigated could have influenced the final results. It was verified that the sizes measured were in accordance with known trends for mysidacea (Allen, 1984; Mauchline, 1968, 1980; Wooldridge, 1986), and particularly, M. slabberiat the study site (Azeiteiro et al., 1999). Even though the sizes of oocytes could not be compared to those mentioned in other studies, in absolute terms, the size relations between the various stages of oocytical development were quite similar to those observed in other studies.

Upon creation, validation and application of the scale, the most prominent factor emerging from this study is the confirmation of the initial assumption: seasonal variability in 

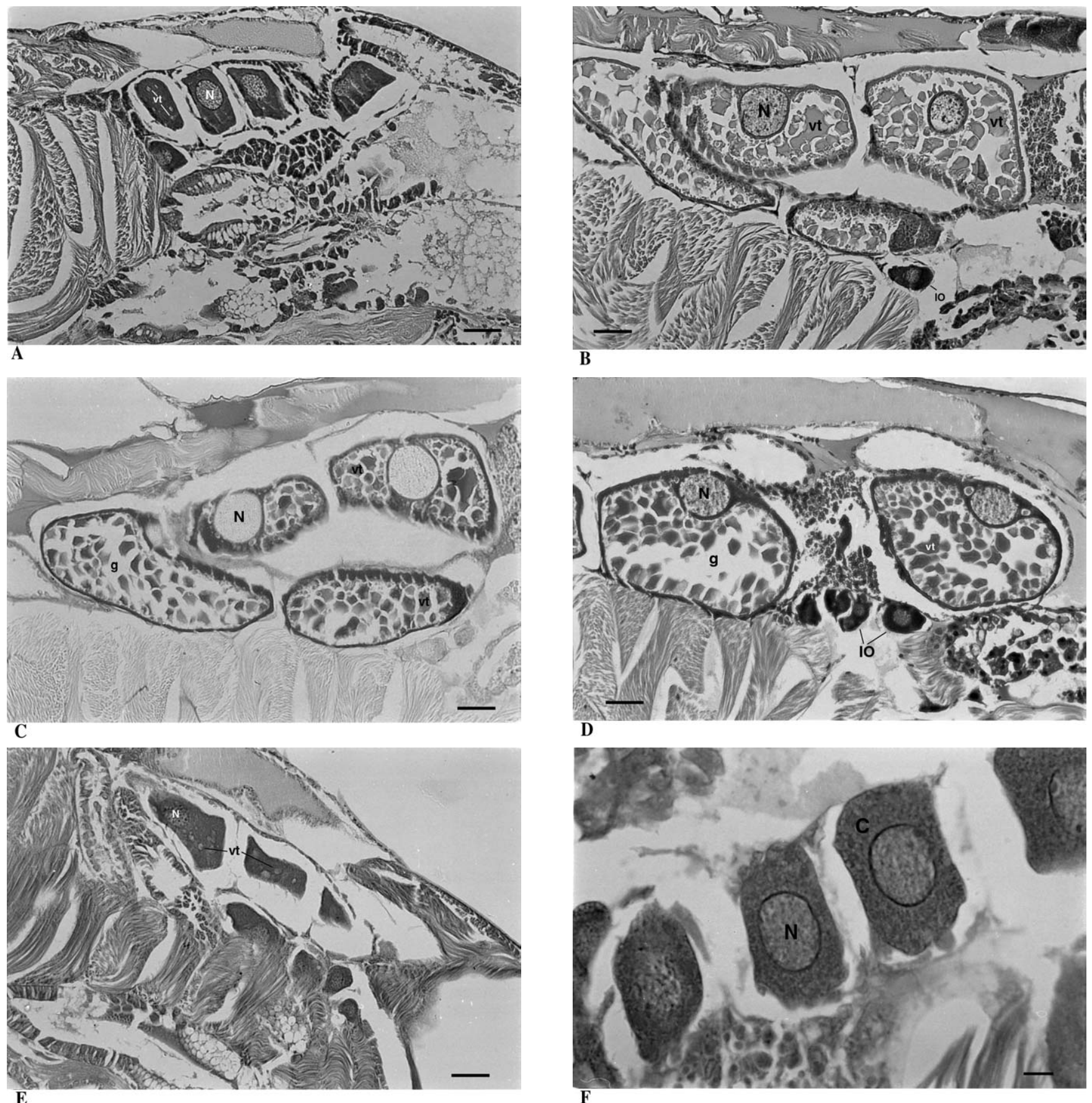

Fig. 2. Mesopodopsis slabberi longitudinal sections. (A) HE staining showing vitellogenic oocytes. Yolk present in droplets in the cytoplasm (total magnification $=235 \times$, scale bar $=50 \mu \mathrm{m}$ ). (B) HE staining showing mature oocytes. Yolk (vt) occupying the majority of the cytoplasm. Co-existence of immature (IO) and mature oocytes (total magnification $=235 \times$, scale bar $=50 \mu \mathrm{m}$ ). (C) PAS technique applied to mature oocytes. Vitellum with polysaccharide residues (vt) occupying the majority of the cytoplasm. Strong positive reaction in the peripheral cytoplasm. Gaps between vitellogenic inclusions due to lipid removal from the cell by the used fixation agent (Bouin's solution) (total magnification $=235 \mathrm{x}$, scale bar $=50 \mu \mathrm{m}$ ). (D) PAS technique applied to mature oocytes, counterstained with alum-hematoxylin. Vitellum with polysaccharide residues occupying the majority of the cytoplasm. Strong positive reaction on the peripheral cytoplasm. Gaps (g) in the cytoplasm due to the removal of lipidic yolk by fixation agent (Bouin's solution). Co-occurrence of immature (IO) and mature oocytes (total magnification $=235 \times$, scale bar $=50 \mu \mathrm{m}$ ). (E) Vitellogenic oocytes submitted to Tetrazonium reaction for proteins. Positive throughout the cytoplasm. Stains denote a weaker response (indicated by vt) corresponding to vitellum of a glycoprotein nature in droplets, as proved by PAS positive testing (total magnification $=235 \mathrm{x}$, scale bar $=50 \mu \mathrm{m}$ ). (F) Vitellogenic oocytes submitted to Tetrazonium reaction for proteins. Positive in the entire cytoplasm. Stains denote a weaker response, corresponding to vitellum of glycoproteic nature as proved by PAS positive testing (total magnification $=929 \times$, scale bar $=10 \mu \mathrm{m}$ ) ( $\mathrm{g}=$ gap; $\mathrm{H}=$ heart; $\mathrm{IO}=$ immature oocyte; $\mathrm{N}$ = nucleus; vt = vitellum) 


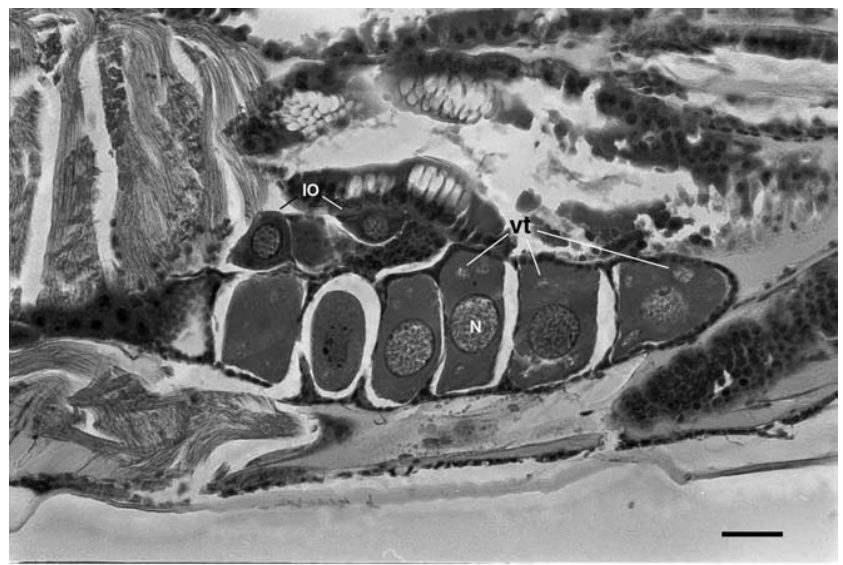

$\mathbf{A}$
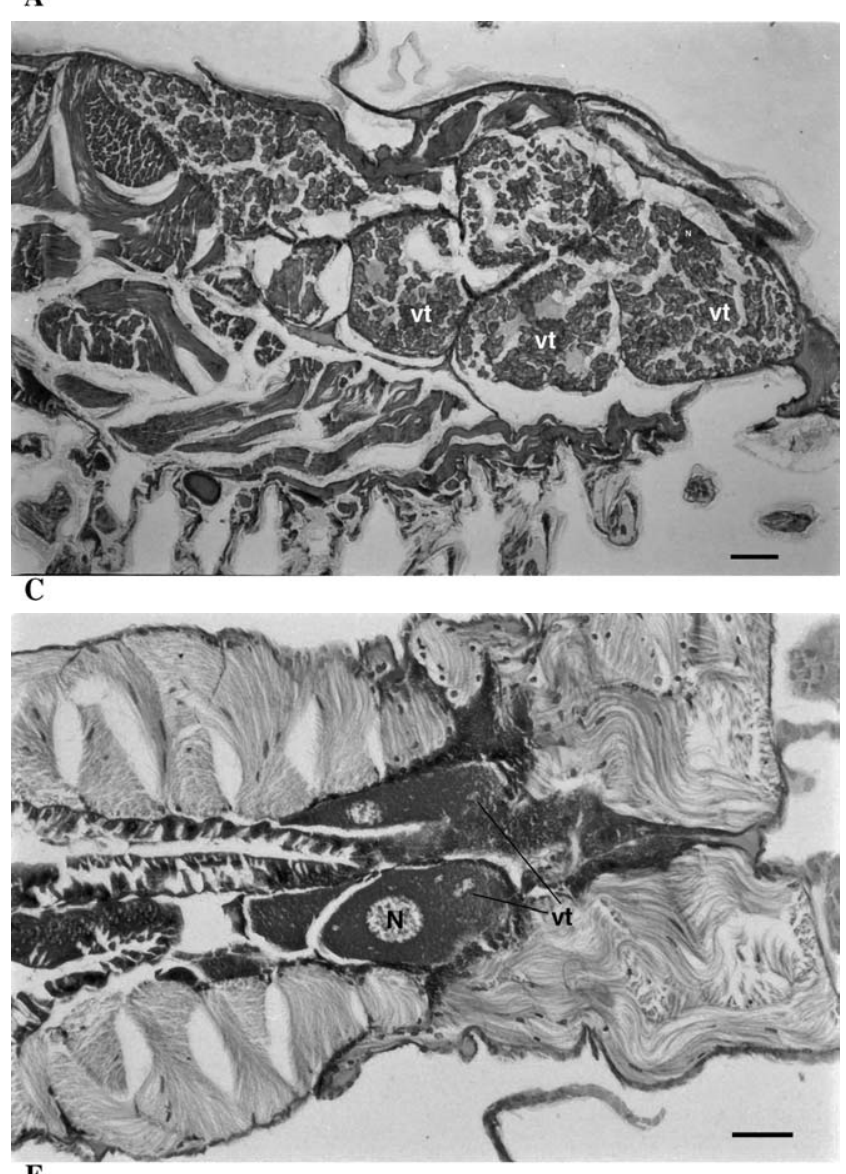

E

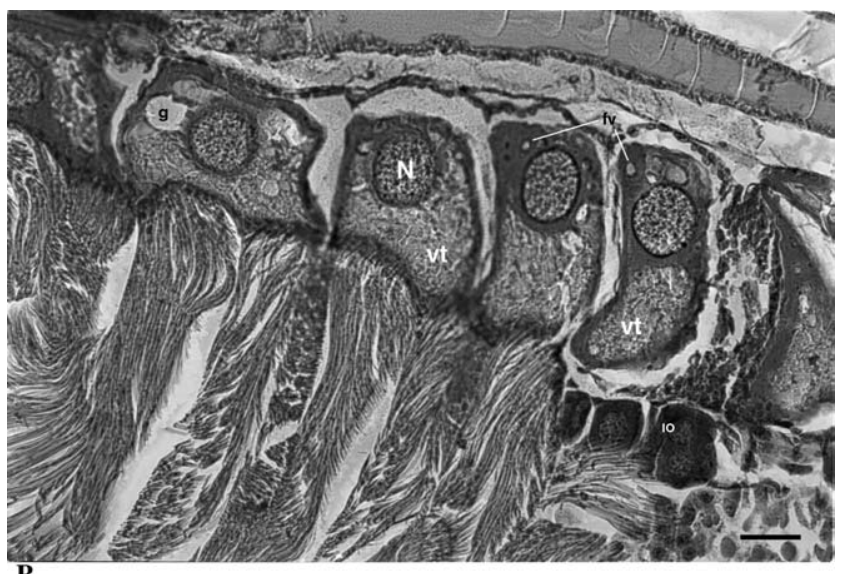

B

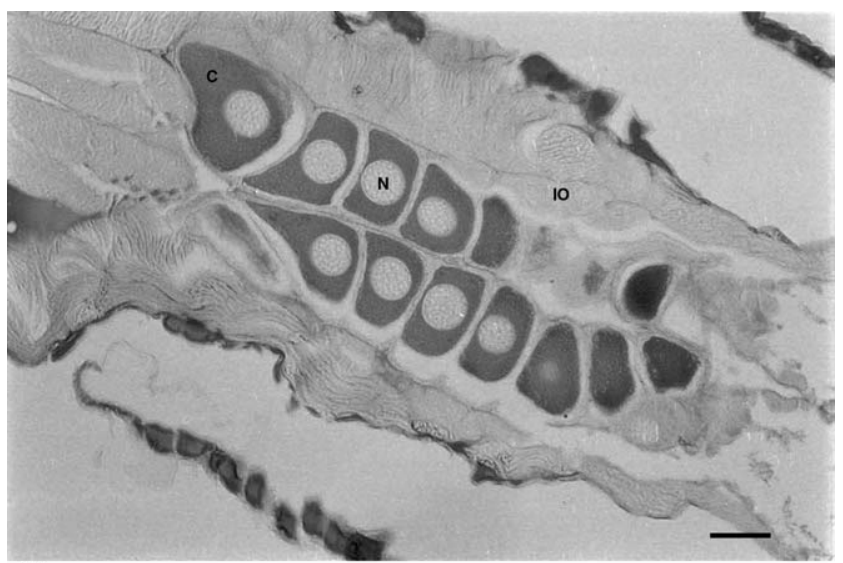

D

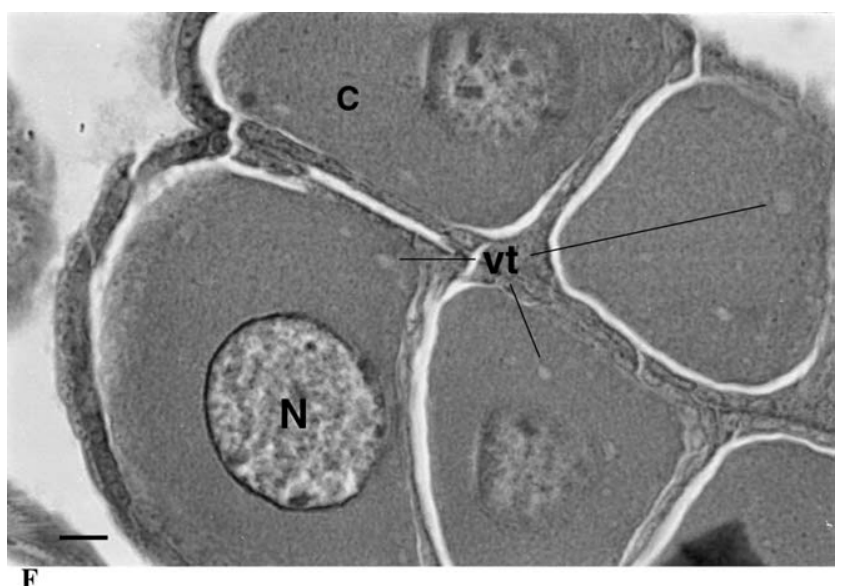

Fig. 3. Mesopodopsis slabberi longitudinal sections. (A) Vitellogenic oocytes (HE staining). Yolk vesicles (vt) present in the cytoplasm. Note the simultaneous presence of immature oocytes $(\mathrm{IO})$ (total magnification $=235 \times$, scale bar $=50 \mu \mathrm{m}$ ). (B) HE staining showing oocytes in an advanced stage of vitellogenesis. Note the presence of vitellum droplets in formation (fv), precluding the total occupation of the cytoplasm, the co-occurrence of immature oocytes (IO) and the existence of gaps (g) due to the removal of lipids due to fixation with Bouin's solution (total magnification $=235 \times$, scale bar $=50 \mu \mathrm{m}$ ). (C) HE staining showing mature oocytes. Entire cytoplasm occupied by yolk (vt) (total magnification $=91 \times$, scale bar $=100 \mu \mathrm{m}$ ). (D) PAS technique applied to Vitellogenic oocytes. Positive reaction throughout the entire cytoplasm (C), indicating glycoproteic uniform dispersion (not in droplets). Notice the co-occurrence of immature oocytes (IO) with a negative response to the technique (total magnification $=235 \times$, scale bar $=40 \mu \mathrm{m}$ ). (E) PAS technique applied to vitellogenic oocytes, counterstained with alum-hematoxylin. Vitellum of a glycoproteic nature (vt) contained in droplets all around the cytoplasm (total magnification $=235 \times$, scale bar $=50 \mu \mathrm{m})$. (F) Vitellogenic oocytes submitted to Tetrazonium reaction for proteins, positive in the cytoplasm. Stains denote a weaker response (indicated by $\mathrm{vt}$ ) corresponding to vitellum of glycoproteic nature as shown by PAS positive testing (total magnification $=929 \times$, scale bar $=10 \mu \mathrm{m})(\mathrm{C}=\mathrm{cytoplasm}$; $\mathrm{g}=\mathrm{gap}$; $\mathrm{H}=$ heart; $\mathrm{IO}=$ immature oocyte; $\mathrm{N}=$ nucleus; $\mathrm{fv}=$ forming vesicles; $\mathrm{vt}=$ vitellum). 
zooplankton densities reflects advantageous or disadvantageous combinations of external factors acting over a latent reproductive potential. Moreover, this work, proves hat histology and histochemistry are valid approaches to the determination of planktonic ecophysiological processes.

\section{Acknowledgements}

The authors would like to express their deep gratitude to Prof. Jorge Rino for all the suggestions, support and overall courtesy, and to Prof. Marina Cunha for technical facilities.

Thanks are due to FCT for supporting this study through programme PRAXIS XXI funding.

\section{References}

Allen, D.M., 1984. Population dynamics of the mysid shrimp Mysidopsis bigelowi Tattersall in a temperate estuary. J. Crust. Biol. 4, 25-34.

Azeiteiro, U.M.M., Jesus, L., Marques, J.C., 1999. Distribution population dynamics and production of the suprabenthic mysid Mesopodopsis slabberi in Mondego river estuary, Portugal. J. Crust. Biol. 19 (3), 498-509.

Bradoshaw, W.E., 1973. Homeostasis and polymorphism in vernal development of Ehaoborus americanus. Ecology 54, 1247-1259.

Castel, J., Courties, C., 1982. Composition and differential distribution of zooplankton in Arcachon Bay. J. Plankton Res. 4 (3).

Cuzin-Roudy, J., Amsler, M., 1991. Ovarian development and sexual maturity staging in Antarctic krill, Euphausia superba Dana (Euphausiacea). J. Crust. Biol. 11 (2), 236-249.

Davis, C.S., 1984. Predatory control of copepod seasonal cycles on Georges Bank. Mar. Biol. 82, 31-40.

Deevey, G.B., 1971. The annual cycle in quantity and composition of the zooplankton of the Sargasso Sea off Bermuda. Limnol. Oceanogr. 16 (2).

Drury, R.A.B., Wallington, E.A., 1980. Carlton's Histological Technique. Oxford University Press, Toronto, Canada, pp. 1-450.

Fulton, R.S., 1984. Predation, production and the organisation of an estuarine copepod community. J. Plankton Res. 6 (3).

Ganter, P., Jollés, G., 1969. Histochimie normale et pathologique. GauthierVillars, Paris.

Gaughan, D.J., Potter, I.C., 1995. Composition, distribution and seasonal abundance of zooplankton in a shallow, seasonally closed estuary in temperate Australia. Estuar. Coast Shelf S. 41, 117-135.

Giesel, J.T., 1976. Reproductive strategies as adaptations to life in temporally heterogeneous environments. Annu. Rev. Ecol. Syst. 7, 57-59.

Gonçalves, F.J., 1991. Zooplâncton e ecologia larvar de crustáceos decápodes no Estuário do Rio Mondego, Tese de Doutoramento, FCT. Universidade de Coimbra, Portugal.

Greenwood, J.G., 1981. Occurrences of congeneric pairs of Acartia and Pseudodiaptomus species (Copepoda, Calanoida). Estuar. Coast Shelf S. 13, 591-596.

Greenwood, J.G., Jones, M.B., Greenwood, J., 1989. Salinity effects on brood maturation of the mysid crustacean Mesopodopsis slabberi. J. Mar. Biol. Assoc. UK 69, 683-694.

Herman, S.S., Mihuroky, J.A., McErlean, A.J., 1968. Zooplankton and environmental characteristics of the Patuxent River Estuary 1963-1965. Chesapeake Science 9 (2), 67-82.

Ianora, A., Buttino, I., 1990. Seasonal cycles in population abundances and egg production rates in the planktonic copepods Centropages typicus and Acartia clausi. J. Plankton Res. 12 (3), 473-481.

Johnston, N.T., 1985. Life History Variation in Neomysis mercedis Holmes (Crustacea, Mysidacea). Ph.D. Thesis. University of British Columbia, Vancouver, BC.
Johnston, N.T., Nothcote, T.G., 1989. Life-History variation in Neomysis mercedis Holmes (Crustacea, Mysidacea) in the Fraser River Estuary, British Colombia. Can. J. Zool. 67, 363-372.

Kiernan, J.A., 1990. Histological and Histochemical Methods - Theory and Practice. second edition. Pergamon Press, Oxford 433 pp.

Kouwenberg, J.H.M., 1994. Copepoda distribution in relation to seasonal hydrographics and spatial structure in the northwestern Mediterranean (Golfe Du Lion). Estuar. Coast Shelf S. 38, 69-90.

Kulkarni, G.K., Glade, L., Fingerman, M., 1991. Oogenesis and effects of neuroendocrine tissues on in vitro synthesis of protein by the ovary of the red swamp crayfish Procambarus clarkii (Girard). J. Crust. Biol. 11 (4), 513-522.

Ladurantaye (De), R., Lacroix, G., 1980. Reparticion Spaciale, Cycle saisonnier et croissance de Mysis litoralis (Banner, 1948) (Mysidacea) dans en fjord subartique. Can. J. Zool. 58 (5), 693-700.

Lanteigne, C., Beninger, P.G., Gionet, C., 1996. Ontogeny of female primary sexual characters in the majid crabs Chionoecetes opilio and Hyas coarctatus. J. Crust. Biol. 13 (3), 501-514.

Levins, R., 1968. Evolution in Changing Environments. Princeton University Press, Princeton, NJ.

Mackas, D.L., 1992. Seasonal cycle of zooplankton of south-western British Columbia. Can. J. Fish. Aquat. Sci. 49.

Mallin, M.A., 1991. Zooplankton abundance and community structure in a mesohaline North Carolina estuary. Estuaries 14 (4), 481-488.

Mark, G.A., 1982. An experimental study of evolution in heterogeneous environments: phenological adaptation bya bruchid beetle. Evolution 36, 984-997.

Marques, J.C., Maranhão, P., Pardal, A., 1993. Human impact assessment on the sub tidal macrobenthic community structure in the Mondego River Estuary (western Portugal). Estuar. Coast Shelf S. 37, 403-419.

Mauchline, J., 1968. The biology of Erythrops serrata and E. elegans [Crustacea Mysidacea]. J. Mar. Biol. Assoc. UK 48, 455-464.

Mauchline, J., 1980. The biology of mysids and euphausids. Adv. Mar. Biol. $18,1-219$.

Morgado, F.M., 1993. Zooplâncton dos canais a Norte da Ria de Aveiro: ciclo anual de abundância. Boletim UCA Universidade do Algarve. UCTRA 1, 380-399.

Ritchie, G., Mordue (Luntz), A.J., Pike, A.W., Rae, G.H., 1996. Morphology and ultrastructure of the reproductive system of Lepeophtheirus salmonis (KrØyer, 1837) (Copepoda, Caligidae). J. Crust. Biol. 16 (2), 330-346.

Rodrigues, V., Guerrero, F., Bautista, B., 1995. Egg production of individual copepods of Acartia grani Sars from coastal waters: seasonal and diel variability. J. Plankton Res. 17 (12), 2233-2250.

Ryan, T.H., Rodhouse, P.G., Roden, C.M., Hensay, M.P., 1986. Zooplankton fauna of Killary Harbour: the seasonal cycle of abundance. J. Mar. Biol. Assoc. UK 66, 731-748.

Sandoval Quintero, M.E., Garcia, A., 1998. Stages of gonadal development in the spotted pink shrimp Penaeus brasiliensis. J. Crust. Biol. 18 (4), 680-685.

Tundisi, J.G., 1970. O plâncton estuarino, Contribuições do Instituto de Oceanografia da Universidade de S. Paulo. Série Oceanografia Biológica 19, 1-22.

Webb, P., Perissinoto, R., Wooldridge, T., 1987. Feeding of Mesopodopsis slabberi (Crustacea: Mysidacea) on naturally occurring phytoplankton. Mar. Ecol. Prog. Ser. 38, 115-123.

Webb, P., Wooldridge, T., 1990. Diel horizontal migration of Mesopodopsis slabberi (Crustacea: Mysidacea) in Algoa Bay, southern Africa. Mar. Ecol. Prog. Ser. 62, 73-77.

Wooldridge, T.H., 1986. Distribution, population dynamics and estimates of production for the estuarine mysid Rhopalophtalmus terranatalis. Estuar. Coast Shelf S. 23, 205-223. 